\title{
The Free Exercise Boundaries of Permissible Accommodation Under the Establishment Clause
}

\author{
Jonathan E. Nuechterlein
}

The free exercise clause ${ }^{1}$ instructs the government to lift state-imposed burdens on religion where the costs of doing so are reasonable. Thus, absent a "compelling" state interest, ${ }^{2}$ the government must exempt people from generally applicable requirements that burden their religious obligations. $^{3}$ By contrast, the establishment clause forbids the government to pass laws for the purpose of advancing religion."

According to the Supreme Court, the principles underlying these two clauses are mutually inconsistent." Justice O'Connor remarks: "It is disingenuous to look for a purely secular purpose when the manifest objective of a statute is to facilitate the free exercise of religion by lifting a government-imposed burden." Many commentators agree that such "accommodation" of religion-whether enacted by a legislature or compelled by a court-inevitably reveals a purpose that the establishment clause forbids. ${ }^{7}$

1. U.S. CONST. amend. I reads in part: "Congress shall make no law respecting an establishment of religion, or prohibiting the free exercise thereof ...."

2. See, e.g., Sherbert v. Verner, 374 U.S. 398,406 (1963). Interests that are "compelling" in the free exercise context often would not be "compelling" in the equal protection context (where virtually no interest is compelling). See, e.g., United States v. Lee, 455 U.S. 252, 262-63 (1982) (Stevens, J., concurring) (suggesting that Court applies lower standard in free exercise cases than it professes). Thus, the required state interest is more aptly termed "substantial."

3. See Frazee v. Illinois Dep't of Employment Sec., 109 S. Ct. 1514 (1989) (state must exempt Sabbath observers from general requirement that welfare candidates accept available employment on any given day of week); Hobbie v. Unemployment Appeals Comm'n, 480 U.S. 136 (1987) (same); Sherbert, 374 U.S. 398 (same); Thomas v. Review Bd., 450 U.S. 707 (1981) (state must exempt Jehovah's Witness from general requirement that welfare candidates accept available employment at any workplace, including munitions plants); Wisconsin v. Yoder, 406 U.S. 205 (1972) (state must exempt Amish from general requirement that all children under 16 attend school).

4. See, e.g., Abington School Dist. v. Schempp, 374 U.S. 203, 222 (1963). Under current doctrine, the establishment clause also prohibits the government from passing laws that have the "primary effect" of advancing religion or that "excessively entangle" church with state. See, e.g., Lemon v. Kurtzman, 403 U.S. 602, 612-13 (1971). These considerations are essentially irrelevant to my analysis. See infra note 57.

5. See, e.g., Walz v. Tax Comm'n, 397 U.S. 664, 668-69 (1969):

The Court has struggled to find a neutral course between the two Religion Clauses, both of which are cast in absolute terms, and either of which, if expanded to a logical extreme, would tend to clash with the other... . The course of constitutional neutrality in this area cannot be an absolutely straight line....

6. Wallace v. Jaffree, 472 U.S. 38,83 (1985) (O'Connor, J., concurring).

7. See, e.g., Choper, The Religion Clauses of the First Amendment: Reconciling the Conflict, 41 
The Court often resolves this problem by ignoring it. ${ }^{8}$ Among commentators, the solutions are varied. Many argue that although the free exercise and anti-establishment principles contradict each other, the free exercise principle should prevail in cases of conflict. ${ }^{\circledR}$ Other commentators deny the religion clause conflict by declaring that the anti-establishment principle permits the government to lift virtually any burden on religion, however slight the burden may be, and however great the cost of lifting it. ${ }^{10}$ Having thus eviscerated the establishment clause, these latter commentators pave the way for many accommodations of religion that the free exercise balance ${ }^{11}$ would not require.

I propose a different approach to understanding the relationship between the religion clauses. I begin with the premise that the establishment clause does principally forbid the state to act with a religious purpose. I conclude that this emphasis on purpose does not place anti-establishment and free exercise principles in contradiction. Rather, it enables us to fit the two principles together like pieces in a jigsaw puzzle.

I will argue the following. The free exercise clause stands for the principle that the government should accommodate ${ }^{12}$ religion unless an impor-

U. PrTT. L. REv. 673, 685-86 (1980); Garvey, Freedom and Equality in the Religion Clauses, 1981 SuP. Cr. REv. 193, 211-13; Gianella, Religious Liberty, Nonestablishment, and Doctrinal Development-Part I. The Religious Liberty Guarantee, 80 HARv. L. REv. 1381, 1388-89 (1967); cf. Ely, Legislative and Administrative Mativation in Constitutional Law, 79 YALE L.J. 1205, 1313-14, 1319-20 (1970) (court-ordered free-exercise exemptions impermissibly favor religion over nonreligion).

8. See Thomas, 450 U.S. at 722 (Rehnquist, J., dissenting); Sherbert, 374 U.S. at 414, 416 (Stewart, J., concurring in result).

9. See, e.g., L. Tribe, American Constitutional Law $\S 14-8$, at 1201 (1988); Gianella, supra note 7 , at 1389 . The Court itself once came very close to this position. See Yoder, 406 U.S. at 220-21.

Some commentators refine this approach by distinguishing, within the zone of overlap, between free exercise claims that trump the establishment clause and those that do not. See, e.g., Choper, supra note 7, at 690-95 (1980) (free exercise clause trumps except where accommodation impairs others' religious freedom-including "liberty" of taxpayers not to fund other people's religious exercise); Garvey, supra note 7, at 218-21 (free exercise clause trumps where net effect of accommodation is to reduce government influence over religious choices).

By contrast, Philip Kurland argues that the Constitution forbids the state ever to classify in terms of religion to confer a benefit. Kurland, Of Church and State and the Supreme Court, 29 U. CHI. L. REv. 1 (1961). From this vantage, the anti-establishment principle trumps the free exercise principle.

10. See McConnell, Accommodation of Religion, 1985 Sup. CT. REv. 1, 30-33; Paulsen, Religion, Equality, and the Constitution: An Equal Protection Approach to Establishment Clause Adjudication, 61 Notre DAME L. REv. 311, 337 \& n.116 (1986); cf. Tushnet, The Constitution of Religion, 18 Cons. L. REv. 701 (1986) (republican values justify expanded role of religion in society); Tushnet, The Emerging Principle of Accommodation of Religion (Dubitante), 76 GEo. L.J. 1691, 1699-1701 (1988) [hereinafter Emerging Principle] (political logrolling arguably justifies most accommodations); Lupu, Keeping the Faith: Religion, Equality and Speech in the U.S. Constitution, 18 ConN. L. REv. 739, 762-66 (1986) (establishment clause permits state to accommodate individuals but not groups).

11. See supra notes 1-3 and accompanying text; infra note 93 and accompanying text.

12. I define "accommodation" to mean any action by the government (i.e., courts, legislatures, administrative agencies, etc.) that lifts some identifiable burden on the exercise of religion. See McConnell, supra note 10, at 30-35 (employing similar definition). Typically-and for the purposes of this Note-accommodation lifts a burden imposed by generally applicable rules of conduct or procedure. This burden must hit religious people harder than the public at large. See infra text accompanying note 74 . 
tant state interest precludes doing so-i.e., unless the secular $\operatorname{costs}^{13}$ of accommodation are high. ${ }^{14}$ When the state acts according to this principle, it acts out of a secular respect for the needs of religious people. The internal logic of the anti-establishment principle permits the state to pursue this goal. By contrast, where the free exercise principle does not require accommodation, the state generally cannot accommodate without revealing an illicit religious purpose. Thus, an accommodation manifests a religious purpose either if it does not lift an identifiable burden on religion or if the secular costs of accommodation are high. In short, the traditional freeexercise test defines the permissible limits of state accommodation of religion under the establishment clause.

In Section I, I will argue that the establishment clause principally forbids the state to act with a religious purpose. In Section II, I demonstrate that religious accommodation does not always manifest such a purpose. Finally, in Section III, I illustrate why the traditional free exercise formula enables courts to discern where religious accommodation does manifest such a purpose.

\section{Race, Religion, and Legislative Purpose}

Reconciling the religion clauses requires an inquiry into legislative purpose. ${ }^{16}$ Yet interpreting legislative purpose can be a slippery task. To clarify the inquiry, I compare religion clause jurisprudence with equal protection law, where the question of legislative purpose has dominated judicial analysis for years. In this Section, I use the analogy to illustrate how courts can identify religiously motivated legislation and why they should strike it down.

\section{A. The Harms of Illicit Legislative Purpose}

\section{Stigma}

Racist laws convey to the public a message that one race is better than another. ${ }^{16}$ They stigmatize racial minorities. This stigma, by itself, constitutes one of the principal injuries of racist legislation. ${ }^{17}$

An accommodation may lift either a state or a private burden on religion. See infra notes 77,87 Free exercise principles (as embodied in the free exercise balancing formula) may or may not compel an accommodation, even though, by definition, any accommodation inevitably facilitates the "free exercise" of religion. See infra notes 75-93 and accompanying text. And, according to my analysis, an accommodation may or may not violate the establishment clause. See infra notes 84-102 and accompanying text.

13. I define "cost" broadly to include any expense or inconvenience incurred by non-beneficiaries (including the state treasury). Broadly conceived, "state interests" and "costs" are the same.

14. See supra notes 2-3 and accompanying text.

15. On the conceptual convergence of "purpose" with "motive" and "intent," see Ely, supra note 7 , at 1217-21. I use these terms more or less interchangeably.

16. See, e.g., Brown v. Board of Educ., 347 U.S. 483, 494 (1954) (acknowledging stigmatic harm of discrimination).

17. See, e.g., Karst, Why Equality Matters, 17 GA. L. Rev. 245, 247-48 (1983) ("[t]he chief 
Likewise, religiously motivated laws convey to the public a message that one religious belief (or set of beliefs) is true or superior-and, accordingly, that adherents of mainstream faiths are better than nonadherents. When the state conveys such messages (even messages so general as "there is a God") ${ }^{18}$ it encourages the public to think of nonadherents as inferior-as misguided, heretical, or spiritually corrupt. ${ }^{19}$ To borrow from Madison, this kind of message "degrades from the equal rank of Citizens all those whose opinions in Religion do not bend to those of the Legislative authority."20

Last term, the Supreme Court explicitly adopted this insight as the crux of its establishment clause jurisprudence. It held that the Constitution forbids implicit state "endorsements" ment Clause, at the very least, prohibits government from appearing to take a position on questions of religious belief or from 'making adherence to a religion relevant in any way to a person's standing in the political community." "22

As Justice O'Connor puts it, "[e]ndorsement sends a message to nonadherents that they are outsiders, not full members of the political community, and an accompanying message to adherents that they are insiders, favored members of the political community." ${ }^{23}$ Thus the Constitution forbids the state either to endorse religion explicitly (e.g., by declaring

citizenship value is respect; the chief harm against which the [equal protection clause] guards is degradation or the imposition of stigma").

One of the chief disanalogies between the equal protection context and the establishment clause context is that, in the former, stigma and tangible inequality feed on each other, whereas in the latter, tangible inequality (specifically, group poverty) is rarely at issue. Thus, in the equal protection context, a law's effect may itself constitute a harm that is conceptually independent of the law's purpose, whereas in the establishment clause context, a law's effect (arguably) functions primarily as an evidentiary basis from which to infer a stigmatizing, invalidating purpose. See infra notes 41,57 . Yet the central analogy remains: Stigmatizing someone on the basis of her race or religion is itself a harm that the Constitution forbids.

18. See, e.g., Texas Monthly, Inc. v. Bullock, 109 S. Ct. 890, 896 (1989) (plurality opinion) ("[T]he Constitution prohibits, at the very least, legislation that constitutes an endorsement of one or another set of religious beliefs or of religion generally."); Wallace v. Jaffree, 472 U.S. 38, 54 (1985) ("the political interest in forestalling intolerance extends beyond intolerance among Christian sects-or even intolerance among 'religions'- to encompass intolerance of the disbeliever and the uncertain"); Torcaso v. Watkins, 367 U.S. 488, 495 (1961) (state may not pass laws that "aid all religions as against non-believers").

19. See, e.g., Abington School Dist. v. Schempp, 374 U.S. 203, 208 n.3 (1963) (noting popular equation of "atheism" with "communism" and "immorality").

20. J. Madison, Memorial and Remonstrance Against Religious Assessments (1785), quoted in Everson v. Board of Educ., 330 U.S. 1, 69 (1947) (Rutledge, J, dissenting).

21. See County of Allegheny v. ACLU, 109 S. Ct. 3086, 3100-01 (1989).

22. Id. at 3101, quoting Lynch v. Donnelly, 465 U.S. 668, 687 (1984) (O'Connor, J., concurring). This section of Justice Blackmun's opinion received five votes. See id. at 3124 (O'Connor, J., concurring); id. (Brennan, J., concurring). Thus, the Court effectively adopted the "endorsement" analysis previously developed by Justice O'Connor in Lynch and Wallace v. Jaffree, 472 U.S. 38, 67-84 (1985) (O’Connor, J., concurring).

23. Lynch, 465 U.S. at 688 (O'Connor, J., concurring). 
Christianity the national religion) or to convey an implicit "message of endorsement" by passing laws that manifest a religious purpose. ${ }^{24}$

\section{Distorted Process}

Besides stigmatizing racial minorities, racist motivation also justifies judicial intervention in the legislative process. Normally, courts should defer to the products of legislative deliberation. Yet sometimes a kink in the legislative process will so warp deliberation that courts should intervene to protect the public interest. Racism is such a kink. According to John Hart Ely, "[p]rejudice is a lens that distorts reality" ${ }^{25}$ and thereby delegitimates laws enacted for racist reasons.

Likewise, religion alters one's perception of the secular world. Insofar as ours must be a secular government, religious motivation impermissibly distorts legislative deliberation. It warps the government's secular mission and transforms rational debate into theological decree. This threatens all of the harms that the establishment clause is supposed to prevent: stigmatization of religious minorities, religious hegemony, political divisions along religious lines, ${ }^{28}$ corruption of the appropriated religion, ${ }^{27}$ and outright religious persecution. ${ }^{28}$ Thus the Constitution lays down a brightline rule: The state must not pass laws for a religious purpose.

\section{B. Identifying a Religious Purpose}

Because legislatures will rarely declare that they have passed laws for religious reasons, courts confront a difficult task in determining whether a law objectively manifests a religious purpose. ${ }^{29}$ Justice O'Connor addresses this problem by asserting that " $[\mathrm{t}] \mathrm{he}$ relevant issue is whether an

24. Id. at 690 (O'Connor, J., concurring); see, e.g., Estate of Thornton v. Caldor, 472 U.S. 703, 711-12 (1985) (O'Connor, J., concurring). O'Connor is not entirely clear as to how "messages of endorsement" relate to legislative purpose. See Lynch, 465 U.S. at 690 . Yet if an "objective observer," see infra text accompanying note 30 , perceives a "message of endorsement," it follows that an objective court would also infer that the legislature's motives are, in fact, religious.

On occasion, the state might make some unusually sensitive people feel like religious "outsiders" even when it acts for demonstrably permissible reasons. Yet since such people have effectively misinterpreted the government's purpose, courts should set them straight by denying their claims and explaining to them why they are wrong to take offense.

25. J. Ely, Democracy and Distrust 153 (1980).

26. See Lemon v. Kurtzman, 403 U.S. 602, 622 (1971) ("political division along religious lines was one of the principal evils against which the First Amendment was intended to protect").

27. See Everson v. Board of Educ., 330 U.S. 1, 67-68 (1947) (Rutledge, J., dissenting) (quoting Madison to this effect).

28. See L. TRIBE, supra note $9, \S 14-15$, at 1287 ("the path toward the tyrannical marriage of cross and sword may lie along a steeper slope than some suppose").

29. See supra note 15 . The constitutional analysis remains the same whether legislators vote a certain way because they personally are religious or because powerful religious constituents have made them vote that way. In either case, the legislative product conveys a message to religious minorities that they are outsiders. The same point would apply in the equal protection context: Jim Crow laws stigmatize blacks whether the framers of those laws are themselves racist or merely captive to powerful racist interest groups. Either way, courts properly strike such laws down. 
objective observer, acquainted with the text, legislative history, and implementation of the statute, would perceive it as a state endorsement of [religion]." Yo Yet one cannot make an inquiry "objective" simply by declaring it so. This problem has led some to suggest abandoning the inquiry altogether. ${ }^{31}$

At this point it helps to remember that Justice Black once refused to consider racially discriminatory motivation for very similar reasons: "[I]t is extremely difficult for a court to ascertain the motivation, or collection of different motivations, that lie behind a legislative enactment . . . . It is difficult or impossible for any court to determine the 'sole' or 'dominant' motivation behind the choices of a group of legislators." 32 John Hart Ely rejoins: "Justice Black's point persists . . . it will be difficult to prove unconstitutional official motivation. That doesn't prove what he thought it did, that the Court shouldn't look, but it does indicate that more is needed if the rights of minorities are to be adequately protected." that is needed, Ely demonstrates, is the doctrine of suspect classification, a "handmaiden of motivation analysis."

"Special scrutiny" (Ely's name for "strict" or "heightened" scrutiny) imposes a theoretically rebuttable presumption that certain kinds of legislative classification spring from illicit legislative motivation. Thus, racial classifications presumptively spring from an illicit racist purpose. The state may overcome this presumption only by proving that "the classification in issue fit[s] the goal invoked in its defense more closely than any alternative classification would,"35 and, moreover, by showing that its ostensible goal is a weighty one. In sum:

[S]pecial scrutiny, in particular its demand for an essentially perfect

30. Wallace v. Jaffree, 472 U.S. 38, 76 (1985) (O'Connor, J., concurring). On the relation between legislative purpose and "messages of endorsement," see supra note 24.

31. See, e.g., Edwards v. Aguillard, 482 U.S. 578, 636-40 (1987) (Scalia, J., dissenting); McConnell, supra note 10, at 48; Smith, Symbols, Perceptions, and Doctrinal Illusions: Establishment Neutrality and the "No Endorsement" Test, 86 Mich. L. Rev. 266 (1987); Note, "A Picture Held Us Captive": Conceptual Confusion and the Lemon Test, 137 U. PENN. L. REv. 1827 (1989).

Those who criticize an "endorsement" or "purpose" analysis for its indeterminacy often fail to advance a more determinate alternative. Last term, for instance, four Justices proposed gutting the majority's endorsement analysis in favor of a new establishment clause test that would invalidate only those laws that either (1) help create a formal establishment of religion or (2) "coerce" anyone to follow the religious orthodoxy. County of Allegheny v. ACLU, 109 S. Ct. 3086, 3136 (1989) (Kennedy, J., dissenting in part). Yet, as a juridical category, "coercion" is no more determinate than "endorsement." As the Allegheny dissenters concede, "[s]ymbolic recognition or accommodation of religious faith" amounts to forbidden coercion "in an extreme case" (e.g., "the permanent erection of a large Latin cross on the roof of city hall"). Id. at 3137. Thus, unless it is defined strictly in terms of physical compulsion, "coercion" would often take the form of a strong "message of endorsement." The two concepts-coercion and endorsement-would differ only in degree: i.e., in the apparent strength of the state's "symbolic recognition or accommodation of religious faith." Line-drawing would pose the same conceptual problems in either case.

32. Palmer v. Thompson, 403 U.S. 217, 224-25 (1971)

33. J. ELY, supra note 25, at 145 .

34. Id.

35. Id. at $146-47$. 
fit, turns out to be a way of 'flushing out' unconstitutional motivation, one that lacks the proof problems of a more direct inquiry and into the bargain permits courts (and complainants) to be more politic, to invalidate (or attack) something for illicit motivation without having to come right out and say that's what they're doing. ${ }^{36}$

Ely's justification for applying special scrutiny to racial classifications indicates why we should also apply it to laws that employ religious classifications in distributing public benefits. ${ }^{37} \mathrm{He}$ notes that racial prejudice pervades society and, presumptively, the legislatures too. Since racial classifications are so likely to reflect racial prejudice, courts impose upon the government the burden of proving that this is not the case ${ }^{38}$ Religion is similar. It pervades society and the government too. Thus, one suspects that when the state extends benefits specifically to religion, it does so not for some permissible secular purpose, but simply because it favors a particular religion, religious tradition, or some more general religious belief (e.g., "there is a God"). If the government does have some clearly secular goal in mind, it must prove this by showing that its classification fits that goal better than the overtly religious goal that we suspect. ${ }^{39}$

Though something like "special scrutiny" lurks beneath the surface of many of its establishment clause opinions, ${ }^{40}$ the Supreme Court has not explicitly applied it in this context. ${ }^{41}$ Perhaps that is because special scru-

36. Id. at 146 (footnotes omitted); see also Brest, Palmer v. Thompson: An Approach to the Problem of Unconstitutional Legislative Motive, 1971 SuP. Cr. Rev. 95 (similar analysis).

37. Such laws are not the same as those that discriminate against religions along denominational lines. See infra nate 41.

38. J. ELY, supra note 25, at 153.

39. Cf. Paulsen, supra note 10 , at 341 . Paulsen would "scrutinize" religious classifications not for religious purpose (which he considers insufficient to invalidate a statute, id. at 344-45), but for discriminatory religious effect (namely, "coercion" or "inducement" of religion, id. at 314,356 ).

40. In Abington School Dist. V. Schempp, 374 U.S. 203 (1963), for instance, the Court rejected the state's rationale that school prayer promotes "moral values" and "the teaching of literature," intimating that the state could achieve such goals through other means and noting that "the place of the Bible as an instrument of religion cannot be gainsaid." Id. at 223-24. In Stone v. Graham, 449 U.S. 39 (1980), the Court forbade the state to post the Ten Commandments on schoolroom walls; though the state argued that the Decalogue merely taught "the Common Law of the United States," the Court noted that it was not at all narrowly tailored to perform this function. Id. at 41-42. And in Edwards v. Aguillard, 482 U.S. 578 (1987), the Court invalidated Louisiana's "creation science" statute, implying that the law could not advance the state's ostensible purpose ("academic freedom"), id. at 586 n.6, and more plausibly served to promote religious doctrine, id. at 591 . See also Wallace v. Jaffree, 472 U.S. 38 (1985) (discussed infra notes 67-70 and accompanying text).

41. The Court has traditionally analyzed establishment clause claims under the much-maligned "Lemon test," which (read literally) invalidates any law that has the purpose or "primary effect" of advancing religion or that "excessively entangles" church with state. See Lemon v. Kurtzman, 403 U.S. 602, 612-13 (1971). Last term, however, the Court conspicuously substituted Justice O'Connor's "endorsement" analysis for the Lemon test. See supra notes 21-24 and accompanying text.

The cases discussed supra note 40 were all decided under Lemon's "purpose" test (or one of its precursors). Yet even Lemon's "primary effect" test functions as a kind of motivation analysis, since one may (and the Court arguably does) presume that an actor intends the natural consequences of his actions. See Ely, supra note 7, at 1317-18; Merel, The Protection of Individual Choice: A Consistent Understanding of Religion Under the First Amendment, 45 U. CHI. L. REv. 805, 823-29 (1978); Simson, The Establishment Clause in the Supreme Court: Rethinking the Court's Approach, 72 Cornel. L. Rev. 905, 915-23 (1987). 
tiny generally presupposes legislative "classifications" of some sort, and many establishment clause cases do not meaningfully involve them. ${ }^{42}$ Yet, by definition, religious accommodation (whereby the state lifts burdens from religious practice or belief) virtually always involves legislative classification. Here the state inevitably specifies the religious practices that it means to accommodate, along with the weight that religious interests carry in the face of conflicting secular ones.

For this reason, special scrutiny is especially useful for analyzing the motivation that underlies state accommodation of religion. A legislature that wishes to advance its own religious agenda will pass laws that look quite different from laws enacted by a legislature that merely wishes, in the spirit of liberal pluralism, to accommodate religious difference. In Section III, I will suggest a way to infer motivation from the face of an accommodationist law. First, however, I confront the misconception that all accommodations reveal an illicit religious purpose.

\section{Permissible Accommodation and "Secular Respect"}

Against affirmative action Alexander Bickel wrote: "If the Constitution prohibits exclusion of blacks and other minorities on racial grounds, it cannot permit the exclusion of whites on similar grounds; for it must be the exclusion on racial grounds which offends the Constitution, and not the particular skin color of the person excluded."13

Yet, despite the superficial similarity, advantaging whites is fundamentally unlike advantaging blacks. First, the harms are quite different, both in nature and degree. Given our legacy of racism, regular discrimination stigmatizes blacks, whereas "reverse discrimination" does not stigmatize whites. ${ }^{44}$ Second, whereas legislatures discriminate against minorities for

Though the Court has not explicitly applied heightened scrutiny to identify religious motivation underlying state decisions to advantage religion, it has applied "strict scrutiny" to a statute that singled out and discriminated against certain unpopular religious denominations. See Larson v. Valente, 456 U.S. 228 (1982). Such scrutiny identifies a purpose to disadvantage (i.e., persecute) those religions, which arguably would also be a violation of the free exercise clause. See $i d$. at 245 . In the accommodation context, however, there is seldom this question of outright religious persecution. But see infra note 62. Thus the Court has not applied strict scrutiny to accommodationist laws. See Gillette v. United States, 401 U.S. 437 (1971) (upholding law that exempted from draft only those who opposed all wars on religious grounds, and not those-like Catholics-who opposed only "unjust wars"); see also Estate of Thornton v. Caldor, 472 U.S 703 (1985) (applying Lemon test rather than strict scrutiny to law that exclusively benefited Sabbath observers); L. TRIBE, supra note 9, § 14-7, at 1192-93 ("Perhaps the Lemon test applies to laws that alter the status quo in a way that benefits some religions, as is most frequently the case in establishment clause cases, while Larson applies to laws that alter the status quo in a way that burdens some religions.").

42. See, e.g., Lynch v. Donnelly, 465 U.S. 668 (1984) (considering constitutionality of statesponsored Christmas crèche on public property); Marsh v. Chambers, 463 U.S. 783 (1983) (considering constitutionality of legislative prayer ceremony).

43. A. Bickel, The Morality of Consent 132-33 (1975).

44. See Brest, The Supreme Court, 1975 Term-Foreword: In Defense of the Antidiscrimination Principle, 90 HaRv. L. Rev. 1, 17 (1976); Karst, The Supreme Court, 1976 Term-Foreword: Equal Citizenship Under the Fourteenth Amendment, 91 HARv. L. REv. 1, 52-53 (1977). 
illicit (racist) purposes, ${ }^{48}$ "[w]hites are not going to discriminate against all whites for reasons of racial prejudice, and neither will they be tempted generally to underestimate [their own] needs and deserts . . ."48 Bickel and other opponents of "reverse discrimination" err because they take a good rule (colorblindness) too literally and apply it to contexts where it loses its justification. ${ }^{47}$

The same is true of religion clause commentary. Many commentators (and judges) take too literally the principle that the state must not take religion into account and act with the "purpose of advancing religion."18 They forget that this principle primarily forbids the state to advance religion for religious reasons, since only then does the state stigmatize religious minorities and corrupt the process of secular deliberation. The principle simply does not apply to many forms of accommodation. Here the state may purposefully advance religion without endorsing it and without stigmatizing anyone.

According to Justice Rehnquist, accommodation "would clearly serve only a religious purpose. It would grant financial benefits for the sole • purpose of accommodating religious beliefs." ${ }^{39}$ Yet a "religious purpose" is not the same as a "purpose of accommodating religious beliefs." If someone does something for a "religious purpose," then-under the ordinary meaning of the term-she does it because her religious beliefs encourage her to do it and because she thinks that those beliefs are valid. Thus, one goes to church or says grace before meals for a religious purpose. Likewise, when a legislature requires schoolchildren to read the $\mathrm{Bi}-$ ble, it generally does so for a religious purpose: not simply because it thinks that class discipline will benefit from the practice, but also-primarily-because it thinks that Christianity is the true religion and that children should learn about it for the betterment of their souls. ${ }^{51}$

Yet any given accommodation of religion may not have a religious purpose. If someone invites ten people over to dinner and two of them are Hindu, he will probably go out of his way to stock his refrigerator with something besides hamburgers and hot dogs. Yet he does this regardless of, not because of, his own religious beliefs. He does it not because he thinks that his Hindu friends' religious beliefs are true, but simply because accommodating their religious scruples is a respectful thing to do. Label this attitude "secular respect."

45. See supra note 25 and accompanying text.

46. J. ELY, supra note 25, at 170.

47. See Westen, The Empty Idea of Equality, 95 HARv. L. REv. 537, 583 (1982).

48. See supra notes 4,7 and accompanying text.

49. Thomas v. Review Bd., 450 U.S. 707, 726 (1981) (Rehnquist, J., dissenting).

50. Even commentators who see no particular tension between the religion clauses make this semantic mistake. See, e.g., Smith, Separation and the "Secular": Reconstructing the Disestablishment Decision, 67 TEx. L. REv. 955, 992 (1989); Tushnet, Reflections on the Role of Purpose in the Jurisprudence of the Religion Clauses, 27 WM. \& MARY L. REv. 997, 1007 (1986).

51. See, e.g., Abington School Dist. v. Schempp, 374 U.S. 203 (1963) (discussed supra note 40). 
Legislatures or other governmental bodies are no different from individual people in this regard. The Federal Government, for instance, exempts the Native American Church from generally applicable laws forbidding peyote use. $^{62}$ It does this not because it endorses peyote use, but simply because it recognizes that however perverse peyote rituals may seem to ordinary Americans, they are very important to some people. ${ }^{\mathbf{5 3}}$ Accommodating these people simply reflects the government's secular respect for their right to choose their way of life. ${ }^{.4}$

Secular respect also motivates the typical exemption that a court would order under the free exercise clause. In Sherbert $v$. Verner, ${ }^{\mathrm{SB}}$ for instance, the Supreme Court held that a Seventh Day Adventist could decline available Saturday work yet still collect welfare benefits. The Court made this exception not because any of the Justices believed that Saturday really was the Sabbath, but because the Court respected Mrs. Sherbert's religious obligations whether or not they happened to reflect God's will. The Court's free exercise formula ${ }^{56}$ is the very embodiment of secular respect.

In such contexts, accommodating religion threatens none of the harms discussed in Section I. ${ }^{b 7}$ Yet accommodation is not always so innocuous.

52. DEA Miscellaneous Exemptions, 21 C.F.R. $\$ 1307.31$ (1971).

The Supreme Court is scheduled to decide this term whether the free exercise clause requires the state to permit peyote use in religious ceremonies. See Smith v. Employment Div., 307 Or. 68, 763 P.2d 146 (1988), cert. granted, 109 S. Ct. 1526 (U.S. Mar. 20, 1989) (No. 88-1213). For the implications of a decision in the negative, see infra notes 90-93 and accompanying text.

53. Cf. Galanter, Religious Freedoms in the United States: A Turning Point?, 1966 WIs. L. REv. 217, 293 ("Disabled from establishing the ultimate concerns of the majority, government may be permitted to exercise greater forbearance where it promulgates standards which inadvertently impinge on the ultimate concerns of the minority.").

54. Some commentators-like John Garvey-object that all religious exemptions, because they specifically target religion for special treatment, convey a stigmatizing message that the government prefers religion to non-religion. See Garvey, supra note 7, at 209-14. For representative treatments of this and related issues, see Choper, Defining "Religion" in the First Amendment, 1982 U. ILL. L. REv. 579; Ely, supra note 7, at 1319-22; Garvey, Free Exercise and the Values of Religious Liberty, 18 Conn. L. Rev. 779 (1986); Greenawalt, Religion as a Concept in Constitutional Law, 72 Calif. L. REv. 753 (1984); Marshall, Solving the Free Exercise Dilemma: Free Exercise as Expression, 67 Minn. L. Rev. 545 (1983); Merel, supra note 41, at 812-15; Note, Toward a Constitutional Definition of Religion, 91 HARv. L. REv. 1056 (1978).

Garvey's objection to the free exercise principle seems impossible to square with empirical reality. An atheist would be just as willing as a devout Christian to accommodate Hindus and peyote users. Nor need an atheist (or anyone else) construe such accommodations as endorsements of "religion in general." Anyone can feel secular respect for the obligations of religious people. In its constitutional form, the will to accommodate reflects nothing more than the recognition that many rules of general applicability (e.g., Saturday work requirements or mandatory school attendance) offend the religious conscience more profoundly and more commonly than they offend the secular conscience.

On occasion-though this is probably the exception rather than the rule-religious objections to a rule of general applicability coexist with secular objections that are as principled, deep, and non-selfinterested as the religious ones. In these circumstances, secular respect requires the government to accommodate the secular objections no less than the religious ones. $C f$. Welsh v. United States, 398 U.S. 333, 340 (1970) (plurality opinion) (construing religious "conscientious objection" statute to apply to all who hold pacifistic principles "with the strength of traditional religious convictions").

55. 374 U.S. 398 (1963); see also cases cited supra note 3 (constitutionally mandated religious exemptions).

56. See supra notes $2-3$ and accompanying text.

57. One might argue that, quite apart from considerations of legislative purpose, all accommodations are unconstitutional because they have the "primary effect" of advancing religion. See Thomas $v$. 
Often the government will accommodate religion in ways that arguably do manifest a religious purpose. In the next Section, I develop a theory of "special scrutiny" to identify when the government is acting for this purpose.

\section{SCRUtinizing Accommodation}

\section{A. Prelude: Illicit "Accommodation" of Racial Minorities}

Through "special scrutiny," one may infer the purpose behind accommodation by the circumstances surrounding the state's decision to benefit religion. By way of introduction, the following equal protection exercise, first suggested by Kent Greenawalt, ${ }^{59}$ illustrates the "circumstances" that are important to this analysis.

Consider two hypotheticals:

1. At a predominantly white state university, black students have demonstrated for months demanding recognition of their unique cultural status. Among other things, they demand a black dorm and cultural center. The university finally gives in to these demands and designates an old dorm the "African-American House."

2. Blacks have not organized a call for a black dorm. In fact, most blacks seem happy with integrated dorms. Yet, on its own initiative, the administration goes out of its way to build a new dorm expressly for blacks who wish to live with other blacks. Moreover, to get the project going, it offers tuition credits to any black who chooses to live in the dorm.

Some commentators would oppose both (1) and (2) on public policy grounds, contending that whites and blacks should never be segregated,

Review Bd., 450 U.S. 707, 726 (1981) (Rehnquist, J., dissenting) (arguing rhetorically). Granted, the Court usually construes the establishment clause to forbid laws that have such an effect. See, e.g., Lemon v. Kurtzman, 403 U.S. 602, 612-13 (1971). Yet this rule does not apply to the present context.

In the typical establishment clause case, where the majority advantages its own religion without the pretense of "accommodating" it, the "primary effect" of a law is evidence of the state's purpose in enacting it. See supra note 41. Yet in the accommodation context, if a law's purpose is clearly secular, it does not constitutionally matter that the law effectively "advances" religion. So long as the state has non-religious reasons for accommodating religion, it threatens none of the harms that the establishment clause serves to prevent (e.g., stigmatization, religious hegemony, corruption of religion, religious persecution, etc.).

Occasionally, commentators object that forcing people to pay additional taxes to accommodate someone else's religion violates the taxpayers' religious liberty. See, e.g., Choper, supra note 7, at 677-78, 690-95. Granted, many of the Framers of the establishment clause meant to prohibit taxes for the support of religion. Yet the taxes in question were taxes to support officially endorsed religions. In effect, they added injury to insult. It is quite another thing to claim that tax "injury" alone, however nugatory, violates the establishment clause. Implementing secular respect compromises one's own faith no more than feeling it.

58. See supra notes $29-42$ and accompanying text.

59. See Greenawalt, Judicial Scrutiny of "Benign" Racial Preference in Law School Admissions, 75 Colum. L. Rev. 559, 570 n.74 (1975). 
whatever the purpose.$^{60}$ Leaving these objections to one side, most people would agree that (2) would violate equal protection principles and (1) would not. Note that neither of these policies tangibly disadvantages blacks at all. What, then, is so troubling about (2)?

Simply that this policy conveys, to blacks and whites alike, the message that the university wants to keep blacks away from whites (without explicitly segregating them). That purpose both stigmatizes blacks and empowers courts to invalidate the university's policy on the grounds that racial prejudice suffused its origins. ${ }^{81}$ Yet what precisely is it about the policy that reveals its racist purpose?

First, in (1) the blacks had announced their unhappiness with integrated dorms; in (2) they had not, and therefore the university's action looks suspiciously gratuitous. If the university is not acting to accommodate black needs, it is probably acting (at least in part) to accommodate white bigotry. Second, in (1) the university designated the black dorm with negligible effort and expense. In (2), the university spent a surprising amount of money to advance the "black dorm" project. What induced the administrators to go so far out of their way to promote the project? Since racism has traditionally driven whites further out of their way than respect for black culture, one suspects that racism underlies the program.

Thus, to ascertain whether such programs manifest a racist purpose, a court should place itself in the shoes of the university administrators. Does the magnitude of the blacks' unhappiness with integrated dorms outweigh (or at least approximate) the costs to the university of instituting a black dorm? If so, then the court should conclude that the administrators acted for permissible reasons. If not, then the court-along with virtually any onlooker, black or white--should conclude that the administrators acted for racist reasons. In the language of special scrutiny, racism fits the black dorm program more closely than any more laudable purpose.

An analogous inquiry applies to free exercise accommodation. In that context, one can discern a religious purpose behind accommodation if (1) the religious beneficiaries have not demonstrated a burden that generally applicable rules impose upon their religion or (2) the cost of accommodation is high.

\section{B. Suspect Accommodation}

The accommodations that pose the most serious establishment clause questions are those that, while facially neutral, naturally operate to the benefit of mainstream religions. Yet such de facto accommodations of the

60. Cf. Gewirtz, Choice in the Transition: School Desegregation and the Corrective Ideal, 86 Colum. L. REv. 728 (1986) (state should not permit blacks to choose all-black schools over integrated ones). Since these policy grounds generally do not involve questions of purpose, they are irrelevant to the analogy.

61. See supra notes $16-17,25$ and accompanying text. 
majority need not convey a message of endorsement. ${ }^{62}$ The same secular respect that leads the state to accommodate the religious requirements of a few peyote users often leads it to accommodate the religious requirements of mainstream religious observers.

During Prohibition, for instance, Congress permitted the sacramental use of wine in religious ceremonies. ${ }^{\text {es }}$ Whatever one may think of Prohibition itself (imagine arguendo that serious health considerations compelled it), few would think that this exemption necessarily manifests a religious purpose. Most people, regardless of their religion, would approve the exemption because wine at Communion means so much to certain religious people (namely Christians) and because letting them drink it requires so little of anyone else. ${ }^{\text {Bt }}$

Yet accommodation can also flout the First Amendment. The government might accommodate not out of secular respect, but for the illicit purpose of advancing religious positions that it finds theologically meritorious. This purpose violates the establishment clause, no matter how general (e.g., "there is a God") the favored religious position may be. ${ }^{65}$ How, though, are courts to identify the accommodations that arise from this purpose rather than from secular respect?

They should place themselves in the shoes of the state actors and determine which of the two possible purposes (secular respect or religious favoritism) better fits the accommodation in question. In making this inquiry, courts should primarily consider two factors: How great is the burden to be lifted? And how much will lifting it cost non-beneficiaries? These turn out to be the same questions that courts ask when conducting a free exercise inquiry. Thus, where accommodation is concerned, free exercise principles define the boundaries of the establishment clause. As Section III(C) explains, this result is not a coincidence.

\section{Substantiality of Burden as a Factor in Establishment Clause Analysis}

To justify an accommodation under the establishment clause, the state must-at a minimum-show that the accommodation truly accommodates, that it lifts an actual burden on the free exercise of religion. Where it does not lift a burden, the government manifests no purpose beyond the gratuitous advancement of religion. ${ }^{66}$

62. Of course the state may not discriminate against religions. If the state accommodates the religious practices of one religion, it must accommodate any closely analogous practices of other religions.

63. National Prohibition Act, ch. 85, title II, § 3, 41 Stat. 305, 308 (1919) (permitting consumption of "wine for sacramental purposes") (repealed 1935).

64. Cf. Gianella, supra note 7, at 1388 (free exercise clause requires sacramental exemption).

65. See supra notes $18-19$ and accompanying text.

66. See Corporation of the Presiding Bishop v. Amos, 483 U.S. 327, 348 (1987) (O'Connor, J., concurring) ("in order to perceive the government action as a permissible accommodation of religion, 
In Wallace v. Jaffree, ${ }^{87}$ for instance, the Court struck down a "moment-of-silence" statute whose legislative history explicitly revealed an invalidating religious purpose. When Alabama passed this law, it already had a moment-of-silence statute on the books. The principal difference between the two statutes was that the original one designated the silent moment for "meditation," whereas the new one elaborated that the moment was for "meditation or voluntary prayer." that because the addition of these words could not plausibly lift a burden on religion that the earlier statute had not already lifted, the new statute could manifest nothing but a gratuitous endorsement of religion. ${ }^{69}$ That purpose offends the establishment clause. ${ }^{70}$

A more difficult case is Texas Monthly, Inc. v. Bullock, ${ }^{71}$ in which the Court struck down a state tax exemption for religious periodicals. Rejecting the state's argument that the free exercise clause compelled the exemption, the plurality declared: "[T]he State has adduced no evidence that the payment of a sales tax by subscribers to religious periodicals ... would offend their religious beliefs or inhibit religious activity .... No concrete need to accommodate religious activity has been shown."72 Though the plurality made this point to reject the state's free exercise argument, it could have made it to bolster its own conclusion that the exemption "effectively endorses religious belief." T3 The free exercise clause itself embodies the value of secular respect, which in turn is a permissible motive for accommodation under the establishment clause. Thus, if Texas could have justified its policy under the free exercise clause, it could also have justified it under the establishment clause.

there must in fact be an identifiable burden on the exercise of religion that can be said to be lifted by the government action"). Even commentators who do not consider religious purpose dispositive generally require that accommodations lift some burden on religion. See McConnell, supra note 10, at 30-35; McConnell \& Posner, An Economic Approach to Issues of Religious Freedom, $56 \mathrm{U}$. CHI. L. REv. 1, 33 (1989); Paulsen, supra note 10, at 342.

Commentators generally reject the other free exercise factor-the secular consequences of accommodation (see infra notes 75-86 and accompanying text) -as irrelevant to whether an accommodation violates the establishment clause. See, e.g., McConnell, supra note 10, at 30-31; Paulsen, supra note 10, at 337 \& n.116. But cf. Beschle, The Conservative as Liberal: The Religion Clauses, Liberal Neutrality, and the Approach of Justice O'Connor, 62 Norre DAME L. Rev. 151, 188-90 (1987) (accommodation permissible only where its net effect benefits temporal welfare of community; see infra note 85). Not considering this factor would permit many accommodations that this Note would condemn. See infra notes 75-93 and accompanying text.

67. 472 U.S. 38 (1985).

68. Id. at 59 .

69. Id. at 59-60.

70. But see McConnell, supra note 10, at 47-48; Paulsen, supra note 10, at 344-45 (religious purpose should not have been dispositive). Both $\mathrm{McC}$ Connell and Paulsen deny that religious purpose alone should suffice to invalidate a law.

71. 109 S. Ct. 890 (1989).

72. Id. at 901 (plurality opinion); see also Jimmy Swaggart Ministries v. Board of Equalization, 110 S. Ct. 688 (1990) (rejecting similar claim).

73. Id. The plurality distinguished a similar case, Walz v. Tax Comm'n, 397 U.S. 664 (1970), on the grounds that the tax exemption there applied broadly to many kinds of non-profit or quasi-public organizations and not specifically to religious organizations. Id. at 898-901 (plurality opinion). 
Texas Monthly is a difficult yet instructive case because the tax exemption obviously did lift a "burden" (i.e., taxes) on religion. Yet this is not the kind of burden that "accommodation" should lift. Accommodation, properly understood, lifts only those burdens that hit religious people or organizations harder than the public at large. Otherwise, the state could cite virtually anything (e.g., a recessionary fiscal policy) as a "burden" on religion and undertake to "relieve" it with massive subsidies. Accordingly, though sales taxes "burden" any publication, they do not generally burden religious publications more than other kinds (e.g., partisan political magazines). Singling out religious periodicals for special treatment is not "accommodation" at all, but "preferential support for the communication of religious messages."

\section{The Secular Costs of Accommodation as a Factor in Establishment Clause Analysis}

It is not enough for the government to demonstrate that its accommodation lifts an identifiable (and special) burden on religion. It must also show that the secular ${ }^{75}$ costs of making the accommodation are small.

Consider the Connecticut statute at issue in Estate of Thornton v. Cal$d o r,{ }^{78}$ a statute that imposed upon private employers an absolute duty to permit each employee to observe her personal Sabbath. ${ }^{77}$ This law primarily benefited (and was clearly meant to benefit) Christians and Jews. The Connecticut legislature passed it because the Connecticut Supreme

74. Id. at 907 (Blackmun, J., concurring).

75. If the "accommodation" imposes a religious cost on non-beneficiaries, it almost automatically violates the establishment clause. One does not, out of secular respect, shift religious burdens from one group to another. Thus, requiring schoolchildren to read from the Bible-even if most of them are Christian-violates the establishment clause because it necessarily coerces nonadherents into following the religious orthodoxy. See, e.g., Abington School Dist. v. Schempp, 374 U.S. 203 (1963).

76. 472 U.S. 703 (1985).

77. The statute in Thornton lifted a privately-placed burden on religion. Thus, "it is not the sort of accommodation statute specifically contemplated by the Free Exercise Clause." Id. at 712 (O'Connor, J., concurring). Nonetheless, though the free exercise clause does not technically require the government to lift private burdens on religion, the principle underlying that clause (secular respect) often transcends the state action distinction. Secular respect should motivate the government to lift unreasonable regulatory burdens on religion whether it or some large private actor like Caldor placed them there to begin with. Thus the free exercise principle embraces statutes like title VII, 42 U.S.C. $\$ \$ 2000 \mathrm{e}(\mathrm{j}), 2000 \mathrm{e}-2$ (1982), which requires private employers to "reasonably accommodate" the religious needs of their employees. See McConnell, supra note 10, at 31-33; see also Thornton, 472 U.S. at 708-10 (implying that title VII provision is constitutional, since it does not require absolute accommodation).

I seek to reconcile the principles underlying the religion clauses. Those principles remain the same whether they are compulsory or precatory. Cf. McConnell, supra note 10, at 5 ("I shall not here attempt a rigorous distinction between accommodations that are a permissible exercise of governmental discretion under the Establishment Clause and those so important that they are compelled under the Free Exercise Clause .... . [F]rom the perspective of religious liberty, the nature, justification, and limits of accommodation appear essentially the same when accommodations are instituted by elected officials as when they are ordered by judges."); Choper, supra note 7, at 686 (similar approach). 
Court had repeatedly invalidated the legislature's mandatory Sundayclosing laws. ${ }^{78}$

There appeared in the Court's cursory opinions two principal reasons for striking the statute down. First, in her concurrence, Justice O'Connor claimed that because the statute singled out Sabbath observers for special treatment, it effectively endorsed a particular religious belief. ${ }^{79}$ Yet merely singling out a religious practice for special treatment does not necessarily convey a message of endorsement: otherwise, permitting Prohibition-era Christians to drink wine would offend the establishment clause, as would allowing Native Americans to conduct peyote rituals..$^{80}$

Something more is needed to convey a message of endorsement, and the Court glimpsed it in the absolute nature of the Sabbath exemption. The majority opinion, without quite explaining why, struck down the Sabbath law because it "commands that Sabbath religious concerns automatically control over all secular interests at the workplace; the statute takes no account of the convenience or interests of the employer or those of other employees who do not observe a Sabbath." $8 \mathrm{sI}$

Why should it matter whether the exemption is qualified or absolute? This rationale has baffled several commentators. Michael McConnell, for instance, argues that even if the Sabbath law was economically unwise, "[t]he relevant issue is the nature, not the magnitude, of the cost imposed on other parties. Protecting businesses from excessive and unreasonable regulation went out with substantive due process." ${ }^{\text {"82 }}$ Other commentators were less charitable. One called the Thornton opinion "bizarre" and "incomprehensible." 83

Granted, the "convenience and interests" of non-beneficiaries do not rise to the level of a constitutional right. In this sense, the absoluteness of the Sabbath exemption was constitutionally irrelevant. Yet in another, evidentiary sense, this absoluteness revealed precisely what was objectionable about the law. The statute's goal (accommodating religious practices) was legitimate only if Connecticut pursued that goal for the right reasons. Connecticut's failure to consider secular interests, however, indicates that it pursued that goal for the wrong reasons.

There are, to rehash, two basic purposes that might underlie an accommodation of religion. The first is unproblematic: The state simply ac-

78. 472 U.S. at 705 n.2.

79. Id. at 711 (O'Connor, J., concurring).

80. See supra notes 52-54, 63-64 and accompanying text; supra note 62 .

81. 472 U.S. at 709. This was the majority's sole reason for striking the statute down. Justice O'Connor offered this reason in addition to her observation that the beneficiaries of the law come from a single religious tradition. See id. at 711-12 (O'Connor, J., concurring).

82. McConnell, supra note 10 , at $57-58$; see also Lupu, supra note 10 , at 748 ("The distinction between reasonable and absolute accommodation cannot bear the constitutional weight assigned to it in Thornton .... If employers can be required to make any accommodation of religious practice, the establishment clause cannot yield a cost-based principle that limits such requirements.").

83. Paulsen, supra note 10 , at 337 n.115. 
knowledges that religion is very important to some people and accommodates them-but simply out of secular respect, not because it thinks that they adhere to the "right" religion. The second purpose is religious: The state accommodates a religious practice because it thinks that God requires or encourages the practice. When a law manifests this latter purpose, the courts properly strike it down.

How can one tell these two purposes apart? In part, by considering the weight that the state assigns to the religious interest that it accommodates. One will go only so far to respect someone's religious obligations simply for the sake of respect. One will go much farther to please God or implement what one considers transcendent truth. Thus, when a legislature goes far out of its way to accommodate religion, ignoring all kinds of other concerns, one may infer that it acts not simply out of respect, but also to please God.

That was the case in Thornton. By refusing even to consider secular interests, the legislature revealed that its true purpose transcended the secular world altogether. To manifest a legitimate purpose, an accommodation statute must take the secular consequences of accommodation into account. If those consequences are great, the legislature cannot, in constitutional good faith, make the accommodation.

\section{Fitting the Clauses Together}

That final comment leads us back to free exercise analysis. Under the Court's formulation of free exercise principles, if the secular consequences of accommodation are not great ${ }^{84}$ then the legislature should lift the burden on religion. ${ }^{85}$ The free exercise principle defines the limits of permissible accommodation under the establishment clause..$^{86}$

The fit between the religion clauses is not a coincidence. When applying free exercise principles, judges presumably act to protect religious exercise without considering the validity of the religion in question. When judges interpret free exercise principles to require an accommodation, they consider the factors (substantiality of burden, secular cost of accommoda-

84. See supra note 2 and accompanying text; supra note 13.

85. Cf. Beschle, supra note 66 . Beschle argues that court-ordered free exercise exemptions do not convey a message of endorsement if they ultimately "benefit . . . the temporal welfare of the community." Id. at 189. Since he believes that such exemptions "minimize conflict between church and state," he would accordingly support them so long as they do not otherwise "substantially harm the community." Id.

This Note rejects Beschle's empirically questionable premise that court-ordered free exercise exemptions (or, for that matter, accommodations in general) can or should "benefit the temporal welfare of the community." The Note seeks no justification for them beyond the value of secular respect, discussed supra notes 43-57 and accompanying text.

86. By contrast, Michael McConnell asserts that "the elements of a free exercise claim are not apposite to an accommodation freely adopted by the government ... . The relative strength of the governmental interest counter to the accommodation is purely a matter for legislative concern and ought not affect the constitutional analysis." McConnell, supra note 10, at 30-31. 
tion) that anyone acting out of secular respect would naturally apply. When legislatures accommodate religion where judges would not ${ }^{87}$ they ignore these factors and thereby manifest a purpose beyond secular respect. That purpose is almost always religious. ${ }^{88}$

Thus, what judges would consider, legislators should consider. ${ }^{89}$ The free exercise and anti-establishment principles run flush, one against the other. For institutional reasons, however, it does not follow that courts and legislatures can-or should-apply these principles identically.

The Court often remarks that the establishment clause permits the government to make accommodations that a court would not compel under the free exercise clause. ${ }^{80}$ That is not, as one might infer, because judges and legislators should act on different substantive principles when deciding whether or not to accommodate. It is, rather, because deliberative bodies can reasonably disagree on what those principles prescribe in any given case, and, moreover, because judges are naturally more reluctant than legislators to make new law. Legislatures are institutionally in a better position than courts to assess the practical consequences of their exemptions, ${ }^{91}$ and, on the margin, they are more likely than courts to assume responsibility for the costs of accommodating a given religious practice. ${ }^{92}$ From a constitutional perspective, therefore, what matters is not whether the government arrives at some "correct" result when balancing religious burden against secular cost. What matters is whether it tends the free exercise balance ${ }^{33}$ in good faith. Only if the burden is real and the

87. Where the state lifts private burdens on religion, as in Thornton, the relevant establishment clause inquiry is what judges would do if the text of the free exercise clause permitted extension of the free exercise principle (secular respect) beyond the state action context. See supra note 77.

88. It is theoretically conceivable (though empirically quite unlikely) that the state would deliberately promote religion not for religious reasons, but simply to effect some secular benefit (like moral rectitude, public order, etc.). Yet because such deliberate endorsement inevitably stigmatizes nonadherents, the establishment clause forbids the state to promote religion for any reason. See supra notes 21-22 and accompanying text.

89. There are two principal contexts to which this rule does not apply. First, where the state singles out small minority religions (like the Native American Church, see supra text accompanying notes 52-54) for special accommodation, virtually nothing that it does for them would convey an endorsement of their religious positions. Most establishment clause cases, however, involve state advancement of mainstream religions. Second, where the government itself prescribes a moral standard of general applicability (like title VII's prohibition of religious intolerance), exempting religious groups because they disagree with the moral rule cannot imply endorsement of the religious beliefs that spark the disagreement. See, e.g., Corporation of the Presiding Bishop v. Amos, 483 U.S. 327 (1987).

90. See L. TRIBE, supra note 9, § 14-7, at 1194 n.42 (citing cases); see also Texas Monthly, Inc. v. Bullock, 109 S. Ct. 890, 901 n.8 (1989) (plurality opinion); id. at 912-13 (Scalia, J., dissenting).

91. See McConnell, supra note 10, at 31; see also L. TRIBE, supra note 9, $\S 14-7$, at 1195 .

92. The Supreme Court is notoriously quick to find some "compelling state interest" oppasing accommodation. See supra note 2 . Only five times has the Supreme Court interpreted the free exercise clause to extend "special" protection to religious observance-i.e., protection that the free speech clause would not extend to the same conduct. See cases cited supra note 3.

93. In application, the free exercise formula functions as an actual balance. Judges often go beyond the two-tiered inquiry (is there a burden? is there a compelling secular interest?) that they profess and engage in a kind of balancing test that quantifies not simply the secular interest at hand but also the burden on the religion. (For instance, courts often glance sidelong at whether the burden 
costs are reasonable can courts read a secular purpose into the accommodation.

\section{Applications}

From this vantage, Thornton is an easy case: Connecticut had made no effort to tend the free exercise balance at all. ${ }^{94}$ Yet not all cases are so straightforward. Scrutinizing the government's free-exercise "balance" may often require speculative judgments about what secular respect would prescribe in any given case. Nonetheless, the "balance" construct sets the theoretical guidelines-however rough-for determining the constitutionality of religious accommodation. In both free exercise ${ }^{98}$ and establishment clause cases, the greater the burden on religion, the greater the cost the government may/must incur to lift it.

Consider, for example, efforts to relieve the slight but identifiable "burden" that mandatory school attendance places on very religious children. ${ }^{96}$ (The only free schools-public schools-are thoroughly secular and isolate their students from worship for long periods every school day.) The state may not, of course, shift this burden to nonadherents by requiring classroom prayer. ${ }^{97}$ Besides this, however, what the state can do (without betraying a religious purpose) is largely a function of the secular cost that it incurs in accommodating these children.

The state probably may implement moments of silence, which are virtually costless. ${ }^{98}$ It may also permit students to leave school for specified periods to receive privately-sponsored and privately-subsidized religious instruction. ${ }^{99}$ It may not, however, target public funds for the support of religious schools, ${ }^{100}$ even though such appropriations do lift a slight but

threatens a "central" tenet of a religion or requires adherents to "sin.") See Note, Religious Exemptions Under the Free Exercise Clause: A Model of Competing Authorities, 90 YALE L.J. 350, 354-55 \& nn.31, 34; 360-61 \& nn.59-60, 64 (1980) (citing cases).

Perhaps these are questions that courts should not address. Yet perhaps it is inevitable that both courts and legislatures will address them anyway. See $i d$. If that is the case, courts should ensure that legislatures weight the balance pans properly. Just as religiously-motivated legislatures will ignore the secular consequences of accommodation, so too will they exaggerate the burdens to the favored religion, equating what the religion requires with what it encourages.

94. See supra notes 76-83 and accompanying text.

95. See supra note 93.

96. See, e.g., Tushnet, Emerging Principle, supra note 10, at 1710-14.

97. See supra note 75 .

98. Cf. Wallace v. Jaffree, 472 U.S. $38,58-59$ (1984) (implying that moment-of-silence statutes, without damning legislative histories, are constitutional).

99. See Zorach v. Glauson, 343 U.S. 306 (1952).

100. See Grand Rapids School Dist. v. Ball, 473 U.S. 373 (1985); Wolman v. Walter, 433 U.S. 229 (1977); Meek v. Pittenger, 421 U.S. 349 (1975). The Court has upheld facially neutral tax deductions that alleviate the educational expenses of sending children to school, even where the primary beneficiaries are the parents of children at parochial schools. See Mueller v. Allen, 463 U.S. 388 (1983). Such provisions do not classify along religious lines, and the class of beneficiaries is sufficiently broad that special scrutiny, see supra notes $29-42$ and accompanying text, would not apply. Cf. Committee for Pub. Educ. v. Nyquist, 413 U.S. 756 (1973) (striking down tax break targeted only for parents of children at private schools, where most such schools were religious). 
identifiable burden on religion. In this context, the burden on religion is small enough that secular respect alone would not generally motivate granting any remedy with more than a de minimus cost.

By contrast, where the burden on religion is more substantial, the state may (without betraying a religious purpose) incur a greater cost in lifting it. Thus, the state may extend benefits to religious observers where denying those benefits would effectively penalize them for not violating their faith. ${ }^{101}$ Along the same lines, where the state shuts off all access to organized worship for months at a time, as it does when it secludes military personnel in distant outposts, it may-and should-lift the burden by providing chaplains and optional religious services to the willing. ${ }^{102}$

Again, the greater the burden, the farther the state may go in lifting it. Like any other, this formulation does not prescribe a determinate outcome for every case. Nevertheless, it provides a conceptual framework for understanding the limits of permissible accommodation.

\section{Conclusion}

The establishment clause principally forbids the state to act with a religious purpose. The free exercise clause requires the state to treat religious people with secular respect. These two commands are not, as popular theory would have it, in conflict. Rather, the free exercise principle defines the limits of the anti-establishment principle. One begins where the other ends. panying text).

102. See, e.g., Katcoff v. Marsh, 755 F.2d 223 (2d Cir. 1985) (upholding such accommodation against establishment clause challenge). 